\title{
ANTONI CIESZYŃSKI: A TRIBUTE TO A SAVANT
}

\author{
Prejith Sampath, Auswaf Ahsan, Manoj Vengal, Ashir K R \\ Department of Oral Medicine and Radiology, KMCT Dental College, India
}

\begin{abstract}
The first quarter of the twentieth century, following the discovery of X-rays, was a promising time for radiology. It was a time of experimentation and laid the foundations for the science that brought about a radical change in healthcare. Professor Antoni Cieszyński, a Polish physician, dentist, and surgeon, who worked at the University of Lvov during this period, continues to be remembered for his contribution to dentistry as a whole and oral radiology in particular. The professor, accomplished much during a period that was ridden with strife, in a region that was prone to war, between people of different ethnic origins. Despite the odds, he went on to propose several techniques, across fields as varied as oral radiology, periodontology, and oral and maxillofacial surgery, with some of these techniques still being relevant today. As we pass through a century since the 'interbellum, the period between the two world wars, when most of the professor's works were published, we cannot but forget his contributions to dentistry. This tribute serves as an introduction to his early life, his career achievements, and social activities - an inspiration for all of us to emulate, as the science passes through an era of three-dimensional imaging.
\end{abstract}

KEY WORDS: radiography, dental; history, $20^{\text {th }}$ century; Europe, eastern.

J Stoma 2020; 73, 1: 44-46

DOI: https://doi.org/10.5114/jos.2020.94177

\section{INTRODUCTION}

Few dentists have their names permanently engraved in the annals of dentistry, that have lived on into this modern age. One name that comes to mind is that of Professor Antoni Cieszyński, a Polish physician, dentist, and surgeon, who worked at the University of Lvov. Professor Cieszyński is best known for his contribution to radiology, and is credited with the formulation of the rule of isometry, which forms the basis of the bisecting angle technique. His other achievements include the development of an extra-oral technique for anaesthetizing the mandibular nerve, an injection treatment for trigeminal neuralgia, and a flap technique for periodontal surgery. He was a member of several distinguished scientific societies, including Association Stomatologigue Internationall (ASI) and Federation Dentaire Internationale
(FDI), and was the founder of the first Polish dental journal "Polska Dentystyka" [1].

\section{EARLY LIFE}

Antoni Cieszyński was born on May 31, 1882 in Oleśnica, Poland to Tomasz Cieszyński and Emilia Chiżyńska. His father, Tomasz, was no little man himself, having authored the Polish-Latin dictionary "Der Polnische Apotheker" ("Polish Apothecary") in 1880. Young Antoni, after finishing high school in Poznan and Bydgoszcz, moved on to Berlin and Munich, where he studied medicine, dentistry, and philosophy. In 1905, he obtained his diploma in dentistry [2], and was under the guidance of Professor Berten from the Department of Surgery, Professor Otto Walkhof from the Department of Con-

JOURNAL OF STOMATOLOGY CZASOPISMO STOMATOLOGICZNE

AdDRESS FOR CORRESPONDENCE: Dr. Prejith Sampath, Department of Oral Medicine and Radiology, KMCT Dental College, India, e-mail: thetheoreticaldentist@gmail.com 


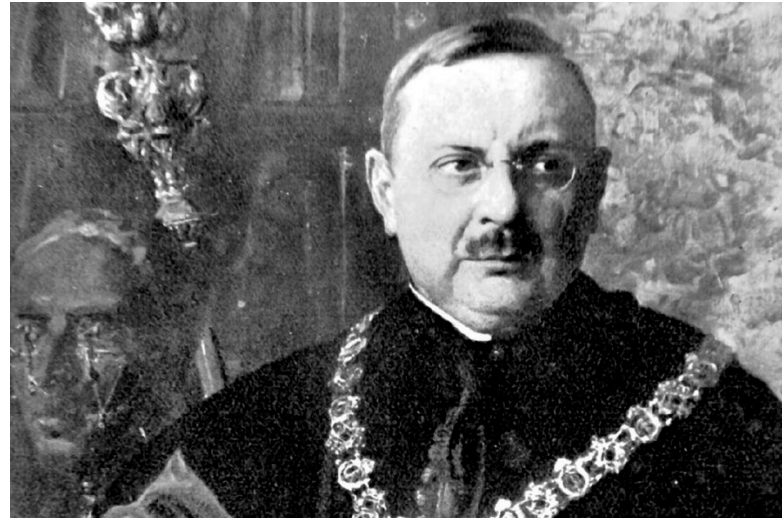

FIGURE 1. Professor Antoni Cieszyński

Source: https://tmlikpw-zarzadglowny.pl/profesor-antoni-cieszynskiczlowiek-niepodleglosci/

servative Dentistry, and Professor Medera from the Department of Prosthodontics. Following his diploma, he obtained his doctor's degree in medicine in December of 1911, with the highest summa cum laude based on the dissertation "On extra-oral imaging of the jaws using X-rays" [3]. Later, in 1915 in Vienna, he married Róża Troczyńska, and had three children: Janina, Tomasz and Hanna [2].

\section{ACADEMIC AND PROFESSIONAL ACHIEVEMENTS}

Cieszyński chose Munich for his education for two reasons: one for its friendly people and the other for his passion for art and literature. He also studied in Berlin, where he worked under Dr Miller from whom he learnt the art of endodontic treatment and wrought gold fillings. His philosophical musings were spent listening to the discourses of Professor Thielego and Professor Dessoir. His fifth semester was a time of incertitude on whether to choose dentistry or medicine as a profession. He chose dentistry, as it would enable him to quickly stand on his own feet and also because of a lack of funds to pursue further studies [4]. He was back in Munich for his sixth semester working under the surgeon Dr Berten, at a time when anesthetic techniques were crude, and most of the procedures were painful to the patient. His persistence to find the right anesthetic led him to experiment with different substances on himself and fell sick in the process, but ultimately culminated in success. An extraoral mandibular injection technique is still in use to date [5].

The first quarter of the twentieth century, following the discovery of X-rays in 1895 by Roentgen, was an exciting time for radiology [6]. While working under Dr Berten in Munich, there was a radiographic apparatus in the basement of the building, in which Cieszyńsky developed a keen interest. After burning his hands holding the image receptors with his finger, and having to take multiple images due to improper positioning of the receptor, he decided to make a film holding device $[5,7]$. The device helped him to reproduce the results with different angulations for the various teeth, and led him to propose the rule of isometry, which forms the basis for the bisecting angle technique $[5,8]$. This technique was able to reproduce images of teeth with near-perfect dimensions. He then created an atlas of radiographic images, the first of its kind, which was exhibited at the Congress of Doctors and Naturalists in Poland in 1907 [5, 9]. Dr Cieszyński was, however, unable to be the first to publish it due to pressure from his superior who wanted to co-author the publication [5].

Following the completion of his doctorate degree in medicine, he was appointed Associate Professor and the Head of the Dental Clinic in the Department of Medicine at the Jan Kazimierz University in Lvov. In 1914, a modernization drive of the infirmary upgraded the status of the outpatient clinic to a Dental Institute, the first of its kind in Poland. During 1926-1927, he was the Dean of the Faculty of Medicine, during which time he wrote the book "The future of the medical state in Poland" [3].

He was a member of numerous national and international societies, and established the Association of Polish Odontologists. He also went on to create the Association of Slavic Dentists at a Congress in Paris. Other positions he held included:

- Chairman of the Universal University Lectures in Lvov (1915-1918);

- Chairman of the Association of Doctors of Dentistry in the Polish State (1913-1923 and from 1935);

- Polish national delegate to the FDI;

- Representative of the Polish Section of the ASI;

- President of the Association of Dentists at the Lvov Medical Chamber [10].

Professor Cieszyński published 378 papers in international scientific journals in seven languages, covering different fields in dentistry [2]. Some extremely worthy of mention are the isometric principle behind the bisecting angle technique, the development of an extra-oral injection technique for inferior alveolar nerve block anesthesia, and an injection treatment for trigeminal neuralgia, which involved the injection of alcohol into the gasserian ganglion [1]. In 1920, a controversy ensued over the priority in the description of the Cieszyński-Widmann-Neumann periodontal flap surgery [11]. However, the introduction of the reverse bevel incision is still attributed to Cieszyński [12].

\section{SOCIAL ACTIVITIES}

When the World War I broke out in 1914, he organized the Polish Red Cross at the Dental Institute where he worked. Following the evacuation from Lvov at the end of 1914, he moved to Tarnów, and later to Vienna, where 


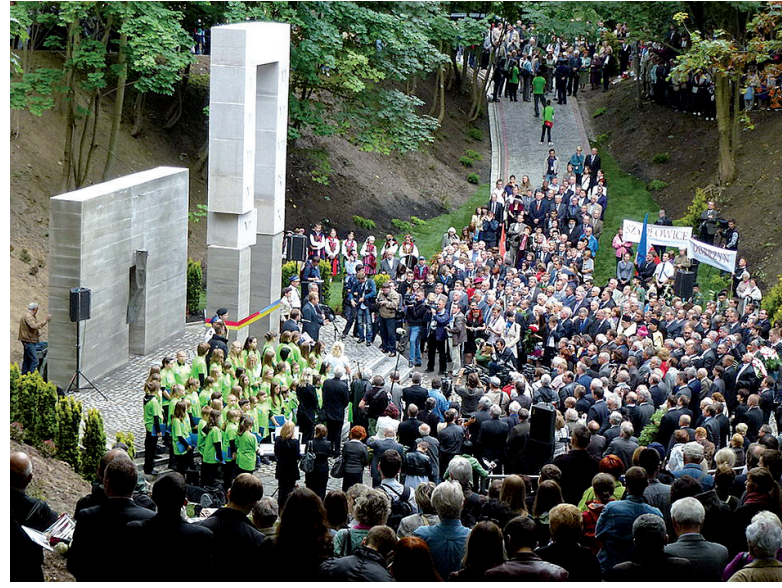

FIGURE 2. Memorial at Wuleckie Hills dedicated to the victims of Lvov massacre

Source: Stanislaw Kosiedowski - own work, CC BY-SA 4.0, https://commons.wikimedia.org/w/index.php?curid=15777339)

he established a ward for maxillary injuries and a dental polyclinic for refugees from Poland. After returning to Lvov, he set up the "Polish Sanitary Service" during the period of fighting against Ukrainians (1918-1919). He organized dressing points for the wounded in the part of Lvov occupied by Ukrainians and was awarded the Cross of Defense of Lvov (1918) and the Medal of Independence (1933) for his efforts [3]. Cieszyńskiego is a street in the birthplace of the Professor, which is named after him in remembrance of his contributions to his homeland.

\section{HIS LAST DAYS}

In July of 1941, during World War II, the advancing Nazi German occupation forces arrested and killed 25 Polish academics at Wuleckie Hills along with their families, in what would later come to be infamously known as the Lvov massacre [13]. Professor Cieszyński, aged 59 was among those killed. The Nazis intended to weaken the resolve of the Polish resistance movement by targeting prominent citizens and intellectuals.

\section{CONCLUSIONS}

Professor Cieszyński’s works have transcended time, with not many having achieved what he has. It is especially remarkable that he has contributed considerably to more than one field of dentistry, which is a tremendous achievement. With the arrival of CBCT, radiology is at a juncture similar to that of Cieszyński's time. His unwavering faith in himself, combined with the urge to transform needs into inventions are qualities for all of us to emulate. Oral radiologists, periodontists, and oral and maxillofacial surgeons might all have come across a mention of Professor Cieszyński during their studies.
The omission of his first name, as is the tendency with formal English literary writing and his association with different branches of dentistry is bound to create a sense of dissociation. This tribute is intended to make one aware that the genius is one and the same.

\section{References}

1. Maciejewska I, Chomik E, Cieszyński A. Antoni Cieszyński: a pioneering dentist. J Hist Dent 2012; 60: 18-22.

2. W hołdzie Profesorowi. Panorama Oleśnicka, Jun 2002, 48. Available at: https://www.olesnica.org/ Antoni_Cieszynski.htm [Accessed: 10.02.2020].

3. Antoni Cieszynski. Available at: https://www.olesnica.org/Antoni_Cieszynski.htm [Accessed: 10.02.2020].

4. Kuźnik P. Excerpts from Księga Pamiątkowa. Available at: http:// www.infodent24.pl/lifedentpost/historia-stomatologii-piotra-kuznika-odc-2-sylwetka-prof-antoniego-cieszynskiego,6204. html [Accessed: 10.02.2020].

5. Kuźnik P. Excerpts from Księga Pamiątkowa. Available from: http:// www.infodent24.pl/lifedentpost/historia-stomatologii-piotrakuznika-odc-3-sylwetka-prof-antoniego-cieszynskiego-2,7187. html [Accessed: 10.02.2020].

6. Röntgen WC. On a new kind of rays. Science 1896; 3: 227-231.

7. Cieszyński A. Verbesserte Modelle von Filmhaltern fur Zahnaufnahmen mittels Rontgenstrahlen. Deut Zahnarztl Woch 1909; 8: 668-670.

8. Cieszyński A. Beitrage zu intraoralen Aufnahmen der Zahne. I. Die Einstellung des Huptstrahes bei intraoralen Zahnaufnamen mittels einwr Orientierungstafel, 1907. Available from: https://www.olesnica.org/Antoni_Cieszynski.htm [Accessed: 10.02.2020].

9. Cieszyński A. Atlas radiologiczny zdjęć dentystycznych. 1907. Available at: https://www.olesnica.org/Antoni_Cieszynski.htm [Accessed: 10.02.2020].

10. UJK we Lwowie - rok akademicki 1935/1936. Available from: http://www.lwow.home.pl/ujk/1.html [Accessed: 10.02.2020].

11. Newman MG, Takei H, Klokkevold PR, Carranza FA. Newman and Carranza's Clinical Periodontology. Thirteenth Edition. Elsevier Health Sciences; 2018: 102. Available at: http://www.elsevierhealth.com/9780323523004 [Accessed: 10.02.2020].

12. Staffileno Jr H. Palatal flap surgery: Mucosal flap (split thickness) and its advantages over the mucoperiosteal flap. Journal of Periodontology - Periodontics 1969; 40: 547-553.

13. Redzik A. Polish Universities during the Second World War. Available at: www.gomezurdanez.com/polonia/adamredzikpolishuniversitas.pdf [Accessed: 10.02.2020]. 